\title{
Effect of biovita granules and liquid on growth and yield of cotton (Gossypium hirsutum L.)
}

\author{
Y. M. Ramesha ${ }^{*}$, Bhanuvally Manjunatha ${ }^{2}$, Ashok Kumar Gaddi ${ }^{2}$ and D. Krishna Murthy ${ }^{1}$ \\ ${ }^{1}$ Department of Agronomy, University of Agricultural Sciences, Raichur, (Karnataka), INDIA \\ ${ }^{2}$ Department of Soil Science and Agricultural Chemistry, University of Agricultural Sciences, Raichur, \\ (Karnataka), INDIA \\ *Corresponding author. E-mail: rameshaym@gmail.com \\ Received: December 27, 2016; Revised received: March 17, 2017; Accepted: August 27, 2017
}

\begin{abstract}
A study was conducted on effect of biovita granules and liquid on growth and yield of cotton during Kharif 2014 and 2015 in deep black soil at ARS, Dhadesugr, University of Agricultural Sciences, Raichur, Karnataka. Pooled data revealed that, cotton yield and green biomass yield were significantly $(p=0.05)$ higher in the treatment with the application of biovita granule at $12.5 \mathrm{~kg}$ per hectare at one month after sowing followed by first spray of biovita liquid at $500 \mathrm{ml}$ per hectare at square formation followed by second spray of biovita liquid at $750 \mathrm{ml}$ per hectare at flowering and followed by third spray of biovita liquid at $750 \mathrm{ml}$ per hectare at boll formation $(1450 \mathrm{~kg} / \mathrm{ha}$ and $1463 \mathrm{~g} /$ plant, respectively) and which was on par with the application of biovita granule at $10.0 \mathrm{~kg}$ per hectare at one month after sowing followed by first spray of biovita liquid at $500 \mathrm{ml}$ per hectare at square formation followed by second spray of biovita liquid at $750 \mathrm{ml}$ per hectare at flowering and followed by third spray of biovita liquid at $750 \mathrm{ml}$ per hectare at boll formation (1377 kg/ha and $1439 \mathrm{~g} / \mathrm{plant}$, respectively). Whereas, application of only recommended dose of fertilizer recorded significantly less cotton and green biomass yield compared to other treatments. The average per cent of increase in yield in biovita applied treatments $\left(T_{1}\right.$ to $\left.T_{8}\right)$ over the no application of biovita treatment $\left(T_{9}\right)$ was $7.13 \%$.
\end{abstract}

Keywords: Biovita, Bolls, Boll retention, Cotton yield, Economics

\section{INTRODUCTION}

Cotton is the most important fibre crop of India grown both under irrigated and rainfed conditions and has played a vital role in the agriculture based Indian economy. India is the third largest cotton producer in the world, occupying about 9 million hectares with a production of about 24.3 million bales in 2015-16. It accounts for 25 percent of world's total cotton area and 12 percent of global cotton production. However, the productivity of $448 \mathrm{~kg} \mathrm{ha}^{-1}$ is still far lower than the world average of $718 \mathrm{~kg} \mathrm{ha}^{-1}$. The average yields in India are the lowest among the top 10 global cotton producers. There is a need to improve the yield and fibre quality of cotton. Various factors responsible for low productivity are non availability of quality seed of approved cultivars, unbalanced use of fertilizers, and deficiency of certain important micronutrients. Besides, shedding of reproductive parts like squares and young bolls are the common problems in cotton, which results in lower cotton yields. The use of certain growth regulators and micro-nutrients was found to be beneficial in increasing the seed yield and quality in cotton (Anon., 1995). Apart from major nutrients, the essential micronutrients like Boron and Magnesium play a vital role in certain physiological activities such as respiration, meristematic development, chlorophyll formation, photosynthesis, oil synthesis, gossypol and phenoloic compounds developments in cotton. Foliar applications of micronutrients have been widely studied (Karev, 1980, Khuzhanazarov et al., 1983 and Eshanna et al., 2004).

Biovita is an extract from a seaweed Ascophyllum nodosum-a marine plant that has been recognized as an excellent natural fertilizer and a rich source of organic matter. The manufacturer of Biovita M/S PI Industries $L t d$., claims that the application of Biovita enables plants to receive direct benefits from the naturally balanced nutrients and plant growth substances available in this seaweed extract. It is one of the most preferred products in its class as non-polluting, non-toxic natural bio-product. It provides over 60 naturally occurring major and minor nutrients and plant development substances comprising of enzymes, proteins, cytokinins, amioacids, vitamins, gibberlins, auxins, betains etc. in organic form. It contributes to greater microbial activity when applied to soil thus increasing nutrient availability. It is an ideal organic product for better growth and productivity. Moreover, it is compatible with insecticides, fungicides, and fertilizers, which can be used in combination, without additional cost of application. It is non corrosive and can be applied with any 
Y.M. Ramesha et al. / J. Appl. \& Nat. Sci. 9 (3): 1871 -1876 (2017)

Table 1. Application of biovita granule and liquid on growth parameters of cotton.

\begin{tabular}{|c|c|c|c|c|c|c|c|c|c|}
\hline \multirow{3}{*}{ Treatment } & \multirow{2}{*}{\multicolumn{3}{|c|}{ Germination \% at 15 DAS }} & \multicolumn{6}{|c|}{ Plant height (cm) } \\
\hline & & & & \multicolumn{3}{|c|}{60 DAS } & \multicolumn{3}{|c|}{120 DAS } \\
\hline & 2014 & 2015 & Pooled & 2014 & 2015 & Pooled & 2014 & 2015 & Pooled \\
\hline $\mathrm{T}_{1}$ & 94.9 & 94.8 & 94.9 & 69.1 & 68.2 & 68.7 & 106 & 108 & 107 \\
\hline $\mathrm{T}_{2}$ & 95.1 & 95.0 & 95.1 & 70.2 & 71.2 & 70.7 & 110 & 112 & 111 \\
\hline $\mathrm{T}_{3}$ & 95.2 & 95.3 & 95.3 & 69.8 & 69.2 & 69.5 & 108 & 110 & 109 \\
\hline $\mathrm{T}_{4}$ & 95.3 & 95.6 & 95.5 & 71.3 & 73.2 & 72.3 & 111 & 114 & 113 \\
\hline $\mathrm{T}_{5}$ & 91.6 & 92.0 & 91.8 & 73.3 & 75.5 & 74.4 & 114 & 115 & 115 \\
\hline $\mathrm{T}_{6}$ & 91.3 & 91.9 & 91.6 & 75.5 & 78.5 & 77.0 & 116 & 118 & 117 \\
\hline $\mathrm{T}_{7}$ & 90.3 & 90.9 & 90.6 & 74.2 & 76.2 & 75.2 & 115 & 116 & 116 \\
\hline $\mathrm{T}_{8}$ & 90.2 & 90.6 & 90.4 & 77.1 & 79.1 & 78.1 & 118 & 120 & 119 \\
\hline $\mathrm{T}_{9}$ & 90.4 & 90.0 & 90.2 & 68.2 & 68.8 & 68.5 & 105 & 106 & 106 \\
\hline$p=0.05$ & 2.72 & 2.31 & 2.52 & 5.68 & 7.27 & 3.64 & 9.04 & 8.30 & 5.11 \\
\hline
\end{tabular}

Table 2. Number of branches of cotton as influenced by the application of biovita.

\begin{tabular}{lcccccc}
\hline & \multicolumn{5}{c}{ Branches per plant at 100 DAS } \\
\cline { 2 - 7 } Treatments & \multicolumn{7}{c}{ Monopodia } & \multicolumn{3}{c}{ Sympodia } \\
\cline { 2 - 7 } & $\mathbf{2 0 1 4}$ & $\mathbf{2 0 1 5}$ & Pooled & $\mathbf{2 0 1 4}$ & $\mathbf{2 0 1 5}$ & Pooled \\
\hline $\mathrm{T}_{1}$ & 1.58 & 1.65 & 1.62 & 18.2 & 17.5 & 17.9 \\
$\mathrm{~T}_{2}$ & 1.75 & 1.81 & 1.78 & 19.2 & 19.2 & 19.2 \\
$\mathrm{~T}_{3}$ & 1.62 & 1.75 & 1.69 & 18.5 & 18.5 & 18.5 \\
$\mathrm{~T}_{4}$ & 1.85 & 1.85 & 1.85 & 19.5 & 20.3 & 19.9 \\
$\mathrm{~T}_{5}$ & 1.85 & 1.99 & 1.92 & 20.1 & 22.2 & 21.2 \\
$\mathrm{~T}_{6}$ & 2.08 & 2.05 & 2.07 & 23.1 & 24.2 & 23.7 \\
$\mathrm{~T}_{7}$ & 1.91 & 1.95 & 1.93 & 21.2 & 23.1 & 22.2 \\
$\mathrm{~T}_{8}$ & 2.12 & 2.15 & 2.14 & 25.2 & 26.5 & 25.9 \\
$\mathrm{~T}_{9}$ & 1.51 & 1.56 & 1.54 & 17.2 & 16.1 & 16.7 \\
$\mathbf{p}=\mathbf{0 . 0 5}$ & $\mathbf{0 . 2 6}$ & $\mathbf{0 . 2 0}$ & $\mathbf{0 . 1 1}$ & $\mathbf{4 . 6 0}$ & $\mathbf{2 . 1 0}$ & $\mathbf{2 . 2 1}$ \\
\hline
\end{tabular}

standard equipment. It has longer shelf life under normal room storage conditions. It can be applied at all stages of the plant growth from seeding to fruiting. The repeated use of Biovita contributes towards better root system, excellent appearance of plants and greater yield potential in cotton (Ramesh Kumar Gumber et al., 2007). Keeping in view the above said properties of Biovita, attempts were made in the present investigation to study the effect of Biovita granules and liquid on growth and yield of cotton.

\section{MATERIALS AND METHODS}

A study was carried out at ARS, Dhadesugur, University of Agricultural Sciences, Raichur, Karnataka dur-

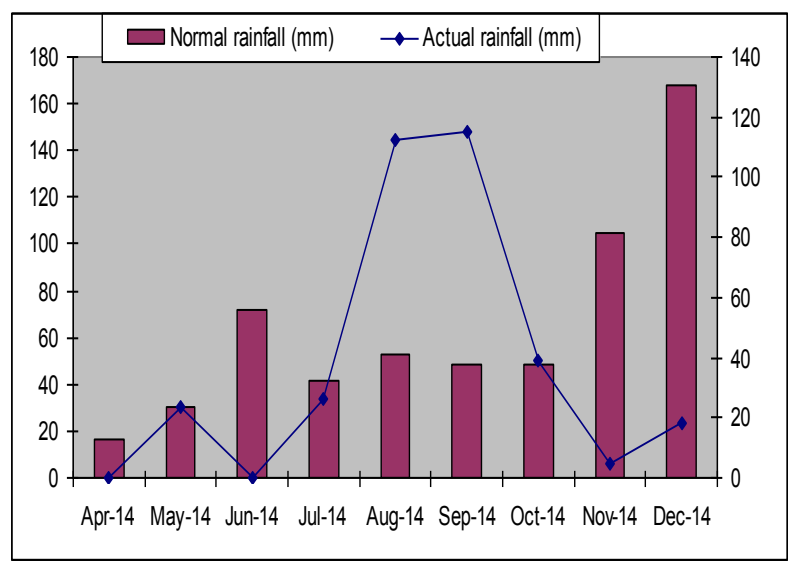

Fig. 1. Monthly rainfall (mm) during Kharif 2014. ing Kharif 2014 and 2015 in deep black soil of uniform topography and texture with slightly alkaline $\mathrm{pH}(8.1)$, low in organic carbon $(0.21 \%)$ and nitro-gen $(160 \mathrm{~kg} /$ ha), medium in available phosphorus $(26 \mathrm{~kg} / \mathrm{ha})$ and high in available potassium (486 kg/ha). The field experiment was laid out in a randomized block design with nine treatments and replicated thrice. The treatments consisted of biovita granule and liquid application viz., T1: Biovita granule followed by 2 sprays of biovita liquid (Biovita granule at $10 \mathrm{~kg}$ at the time of sowing followed by first spray of biovita liquid at 500 $\mathrm{ml}$ at square formation and followed by second spray of biovita liquid at $750 \mathrm{ml}$ at flowering, T2: Biovita granule followed by 3 sprays of biovita liquid (Biovita granule at $10 \mathrm{~kg}$ at the time of sowing followed by first

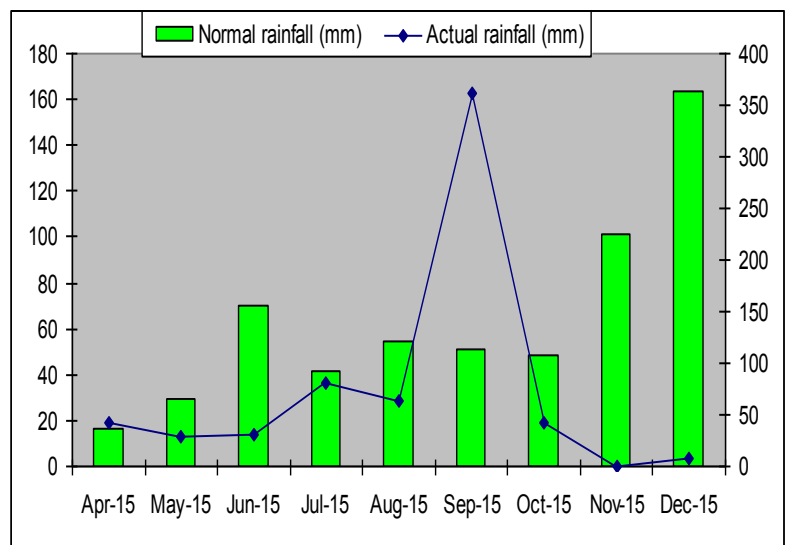

Fig. 2. Monthly rainfall (mm) during Kharif 2015. 
Table 3. Squares and flowers of cotton as influenced by the application of biovita.

\begin{tabular}{lcccccc}
\hline \multirow{2}{*}{ Treatment } & \multicolumn{3}{c}{ Squares per plant at 60 DAS } & \multicolumn{3}{c}{ Flowers per plant at 75 DAS } \\
\cline { 2 - 7 } & $\mathbf{2 0 1 4}$ & $\mathbf{2 0 1 5}$ & Pooled & $\mathbf{2 0 1 4}$ & $\mathbf{2 0 1 5}$ & Pooled \\
\hline $\mathrm{T}_{1}$ & 35.0 & 33.3 & 34.2 & 29.0 & 28.7 & 28.9 \\
$\mathrm{~T}_{2}$ & 35.5 & 35.1 & 35.3 & 31.0 & 31.7 & 31.4 \\
$\mathrm{~T}_{3}$ & 34.1 & 33.8 & 33.9 & 29.2 & 29.2 & 29.2 \\
$\mathrm{~T}_{4}$ & 35.2 & 36.4 & 35.8 & 31.3 & 32.4 & 31.9 \\
$\mathrm{~T}_{5}$ & 35.1 & 36.4 & 35.8 & 31.4 & 32.8 & 32.1 \\
$\mathrm{~T}_{6}$ & 36.1 & 36.5 & 36.3 & 33.3 & 33.8 & 33.5 \\
$\mathrm{~T}_{7}$ & 36.0 & 36.7 & 36.3 & 32.1 & 33.4 & 32.8 \\
$\mathrm{~T}_{8}$ & 36.9 & 36.6 & 36.7 & 34.2 & 34.3 & 34.3 \\
$\mathrm{~T}_{9}$ & 36.2 & 34.5 & 35.3 & 28.4 & 28.0 & 28.2 \\
$\mathbf{p}=\mathbf{0 . 0 5}$ & NS & NS & NS & $\mathbf{1 . 1 3}$ & $\mathbf{1 . 2 7}$ & $\mathbf{1 . 5 2}$ \\
\hline
\end{tabular}

Table 4. Bolls and its weight of cotton as influenced by the application of biovita.

\begin{tabular}{lcccccc}
\hline \multirow{2}{*}{ Treatments } & \multicolumn{3}{c}{ Bolls per plant at 110 DAS } & \multicolumn{3}{c}{ Bolls weight (g) at 110 DAS } \\
\cline { 2 - 7 } & $\mathbf{2 0 1 4}$ & $\mathbf{2 0 1 5}$ & Pooled & $\mathbf{2 0 1 4}$ & $\mathbf{2 0 1 5}$ & Pooled \\
\hline $\mathrm{T}_{1}$ & 27.7 & 27.5 & 27.6 & 93.6 & 85.3 & 89.4 \\
$\mathrm{~T}_{2}$ & 29.9 & 29.5 & 29.7 & 95.9 & 94.7 & 95.3 \\
$\mathrm{~T}_{3}$ & 28.1 & 28.2 & 28.2 & 89.7 & 90.0 & 89.9 \\
$\mathrm{~T}_{4}$ & 30.0 & 31.1 & 30.6 & 102.6 & 102.6 & 102.6 \\
$\mathrm{~T}_{5}$ & 30.2 & 31.5 & 30.8 & 104.4 & 105.5 & 105.0 \\
$\mathrm{~T}_{6}$ & 32.2 & 32.5 & 32.3 & 111.0 & 112.1 & 111.6 \\
$\mathrm{~T}_{7}$ & 31.2 & 32.1 & 31.6 & 108.9 & 109.1 & 109.0 \\
$\mathrm{~T}_{8}$ & 33.2 & 33.1 & 33.1 & 113.8 & 115.9 & 114.8 \\
$\mathrm{~T}_{9}$ & 27.0 & 27.6 & 27.3 & 81.0 & 82.7 & 81.9 \\
$\mathbf{p}=\mathbf{0 . 0 5}$ & $\mathbf{1 . 2 5}$ & $\mathbf{1 . 1 6}$ & $\mathbf{1 . 5 6}$ & $\mathbf{5 . 8 6}$ & $\mathbf{5 . 2 9}$ & $\mathbf{4 . 2 5}$ \\
\hline
\end{tabular}

spray of biovita liquid at $500 \mathrm{ml}$ at square formation followed by second spray of biovita liquid at $750 \mathrm{ml}$ at flowering and followed by third spray of biovita liquid at $750 \mathrm{ml}$ at boll formation), T3: Biovita granule followed by 2 sprays of biovita liquid (Biovita granule at $12.5 \mathrm{~kg}$ at the time of sowing followed by first spray of biovita liquid at $500 \mathrm{ml}$ at square formation and followed by second spray of biovita liquid at $750 \mathrm{ml}$ at flowering), T4: Biovita granule followed by 3 sprays of biovita liquid (Biovita granule at $12.5 \mathrm{~kg}$ at the time of sowing followed by first spray of biovita liquid at $500 \mathrm{ml}$ at square formation followed by second spray of biovita liquid at $750 \mathrm{ml}$ at flowering and followed by third spray of biovita liquid at $750 \mathrm{ml}$ at boll formation), T5: Biovita granule followed by 2 sprays of biovita liquid (Biovita granule at $10 \mathrm{~kg}$ at one month after sowing followed by first spray of biovita liquid at $500 \mathrm{ml}$ at square formation and followed by second spray of biovita liquid at $750 \mathrm{ml}$ at flowering), T6: Biovita granule followed by 3 sprays of biovita liquid (Biovita granule at $10 \mathrm{~kg}$ at one month after sowing followed by first spray of biovita liquid at $500 \mathrm{ml}$ at square formation followed by second spray of biovita liquid at $750 \mathrm{ml}$ at flowering and followed by third spray of biovita liquid at $750 \mathrm{ml}$ at boll formation), T7: Biovita granule followed by 2 sprays of biovita liquid (Biovita granule at $12.5 \mathrm{~kg}$ at one month after sowing followed by first spray of biovita liquid at $500 \mathrm{ml}$ at square formation and followed by second spray of biovita liquid at $750 \mathrm{ml}$ at flowering), T8: Biovita granule followed by 3 sprays of biovita liquid (Biovita granule at $12.5 \mathrm{~kg}$ at one month after sowing followed by first spray of biovita liquid at $500 \mathrm{ml}$ at square formation followed by second spray of biovita liquid at $750 \mathrm{ml}$ at flowering and followed by third spray of biovita liquid at $750 \mathrm{ml}$ at boll formation) and T9: Control. Recommended dose of fertilizer (150:75:75 kg NPK/ha) was applied commonly for all the treatments. The gross plot size for each treatment was $6 \mathrm{~m} \mathrm{x} 4 \mathrm{~m}=24 \mathrm{~m}^{2}$. Land was prepared well and cotton seeds (Ajith 155) were sown on last week of May month in both the years. Biovita granule and liquid was applied as per the treatments. Five plants were randomly selected in each plot of each replication and were tagged for the purpose of recording the observations viz., germination per cent at 15 days after sowing (DAS), plant height at 60 DAS, number of monopodia and sympodia branches at 100 DAS, number of flowers per plant at 75 DAS, number of bolls per plant at 110 DAS, weight of bolls per plant at 110 DAS, number of squares per plant at 60 DAS, Cotton yield (Seed+Lint), Boll retention per cent at $110 \mathrm{DAS}$ and total biomass yield per plant at 120 DAS. Further, cotton yield from each net plot in each replication was harvested and weighed and recorded as cotton yield per net plot and this net plot yield was converted to yield per hectare. The cost of inputs that were prevailing at the time of their use was considered for working out the economics of various treatments. Net return per hectare was calculated by deducting the cost of cultivation from gross returns per hectare, gross returns was calculated by using the total income obtained from cotton yield and the benefit cost ratio was worked out as follows. Benefit cost ratio $=$ Gross returns ( $/$ ha)/Cost of cultivation ( / ha). The 
Y.M. Ramesha et al. / J. Appl. \& Nat. Sci. 9 (3): 1871 -1876 (2017)

Table 5. Yield of cotton as influenced by the application of biovita granules and liquid.

\begin{tabular}{lccccccccc}
\hline \multirow{2}{*}{ Treatments } & \multicolumn{2}{c}{ Boll retention \% at 110 DAS } & \multicolumn{2}{c}{ Cotton (Seed+Lint) yield (kg/ha) } & \multicolumn{2}{c}{ Green biomass yield (g/plant) at 120 } \\
\cline { 2 - 10 } & $\mathbf{2 0 1 4}$ & $\mathbf{2 0 1 5}$ & Pooled & $\mathbf{2 0 1 4}$ & $\mathbf{2 0 1 5}$ & Pooled & $\mathbf{2 0 1 4}$ & $\mathbf{2 0 1 5}$ & Pooled \\
\hline & 79.7 & 82.5 & 81.1 & 1251 & 1255 & 1253 & 1311 & 1324 & 1318 \\
$\mathrm{~T}_{1}$ & 84.5 & 84.2 & 84.4 & 1271 & 1271 & 1271 & 1325 & 1365 & 1345 \\
$\mathrm{~T}_{2}$ & 84.5 & 84.2 & 84.4 & 1271 & 1271 & 1271 & 1325 & 1365 & 1345 \\
$\mathrm{~T}_{3}$ & 85.2 & 85.5 & 85.4 & 1275 & 1275 & 1275 & 1351 & 1379 & 1365 \\
$\mathrm{~T}_{4}$ & 86.2 & 86.5 & 86.4 & 1280 & 1286 & 1283 & 1372 & 1399 & 1386 \\
$\mathrm{~T}_{5}$ & 89.2 & 88.9 & 89.0 & 1347 & 1407 & 1377 & 1425 & 1452 & 1439 \\
$\mathrm{~T}_{6}$ & 86.7 & 87.6 & 87.1 & 1286 & 1295 & 1291 & 1392 & 1412 & 1402 \\
$\mathrm{~T}_{7}$ & 90.0 & 90.5 & 90.3 & 1425 & 1474 & 1450 & 1456 & 1469 & 1463 \\
$\mathrm{~T}_{8}$ & 75.0 & 80.2 & 77.6 & 1215 & 1225 & 1220 & 1214 & 1252 & 1233 \\
$\mathrm{~T}_{9}$ & $\mathbf{4 . 0 0}$ & $\mathbf{3 . 6 5}$ & $\mathbf{3 . 2 5}$ & $\mathbf{1 1 3 . 7}$ & $\mathbf{1 1 5 . 5}$ & $\mathbf{1 2 5 . 3}$ & $\mathbf{1 1 7 . 1}$ & $\mathbf{9 7 . 8}$ & $\mathbf{1 0 2 . 5}$ \\
$\mathbf{p}=\mathbf{0 . 0 5}$ & & & & & & & & &
\end{tabular}

Table 6. Economics of cotton as influenced by the application of biovita (Mean of 2014 and 2015).

\begin{tabular}{|c|c|c|c|c|}
\hline Treatments & Cost of cultivation (//ha) & Gross returns (/ha) & Net returns (/ha) & B:C ratio \\
\hline $\mathrm{T}_{1}$ & 26759 & 56385 & 29626 & 2.11 \\
\hline $\mathrm{T}_{2}$ & 27115 & 57195 & 30080 & 2.11 \\
\hline $\mathrm{T}_{3}$ & 26919 & 57195 & 30276 & 2.12 \\
\hline $\mathrm{T}_{4}$ & 27275 & 57375 & 30100 & 2.10 \\
\hline $\mathrm{T}_{5}$ & 26759 & 57735 & 30976 & 2.16 \\
\hline $\mathrm{T}_{6}$ & 27115 & 61965 & 34850 & 2.29 \\
\hline $\mathrm{T}_{7}$ & 26919 & 58095 & 31176 & 2.16 \\
\hline $\mathrm{T}_{8}$ & 27275 & 65250 & 37975 & 2.39 \\
\hline $\mathrm{T}_{9}$ & 25525 & 54900 & 29375 & 2.15 \\
\hline$p=0.05$ & NA & NA & 5125.2 & 0.15 \\
\hline Materials & Urea & Biovita granule & Biovita liquid & Cotton \\
\hline Prices (Rs/kg) & 20 & 64 & 475 & 45 \\
\hline
\end{tabular}

data was analysed by statistically and tested significance of each treatment (Gomez and Gomez, 1984).

\section{RESULTS AND DISCUSSION}

Effect of biovita on growth parameters of cotton: The pooled data on growth parameters of cotton as influenced by different rate of biovita granule and liquid application is presented in Tables 1 and 2. Results revealed that, Significantly higher germination per cent at 15 DAS was recorded in the treatment with the application of biovita granule at 12.5 and $10.0 \mathrm{~kg}$ per hectare at the time of sowing $\left(\mathrm{T}_{1}\right.$ to $\left.\mathrm{T}_{4}\right)$ compared to other treatments $\left(\mathrm{T}_{4}\right.$ to $\mathrm{T}_{9}$ ) where no application of biovita granules at the time of sowing. Biovita granule application was significantly influenced in improving the germination per cent in cotton. Similarly, application of biovita granule at $12.5 \mathrm{~kg}$ per hectare at one month after sowing followed by first spray of biovita liquid at $500 \mathrm{ml}$ per hectare at square formation followed by second spray of biovita liquid at $750 \mathrm{ml}$ per hectare at flowering and followed by third spray of biovita liquid at $750 \mathrm{ml}$ per hectare at boll formation recorded significantly taller plants $(78.1$ and $119 \mathrm{~cm}$ at 60 and 120 DAS, respectively) and which was onpar with the application of biovita granule at $10.0 \mathrm{~kg}$ per hectare at one month after sowing followed by first spray of biovita liquid at $500 \mathrm{ml}$ per hectare at square formation followed by second spray of biovita liquid at $750 \mathrm{ml}$ per hectare at flowering followed by third spray of biovita liquid at $750 \mathrm{ml}$ per hectare at boll formation (77 and $117 \mathrm{~cm}$ at 60 and 120 DAS, respectively) and application of biovita granule at $12.5 \mathrm{~kg}$ per hectare at one month after sowing followed by first spray of biovita liquid at $500 \mathrm{ml}$ per hectare at square formation and followed by second spray of biovita liquid at $750 \mathrm{ml}$ per hectare at flowering (75.2 and 116 $\mathrm{cm}$ at 60 and $120 \mathrm{DAS}$, respectively). Whereas, application of only recommended dose of fertilizer recorded significantly shorter plants $(68.5$ and $106 \mathrm{~cm}$ at 60 and 120 DAS, respectively) compared to other treatments. Further, monopodial and sympodial branches at 100 DAS were significantly higher in the treatment with the application of biovita granule at $12.5 \mathrm{~kg}$ per hectare at one month after sowing followed by first spray of biovita liquid at $500 \mathrm{ml}$ per hectare at square formation followed by second spray of biovita liquid at $750 \mathrm{ml}$ per hectare at flowering and followed by third spray of biovita liquid at $750 \mathrm{ml}$ per hectare at boll formation (2.14 and 25.9, respectively) and which was onpar with the application of biovita granule at $10.0 \mathrm{~kg}$ per hectare at one month after sowing followed by first spray of biovita liquid at $500 \mathrm{ml}$ per hectare at square formation followed by second spray of biovita liquid at $750 \mathrm{ml}$ per hectare at flowering and followed by third spray of biovita liquid at $750 \mathrm{ml}$ per hectare at boll formation (2.07 and 23.7, respectively) and application of biovita granule at $12.5 \mathrm{~kg}$ per hectare at one month after sowing followed by first spray of biovita liquid at $500 \mathrm{ml}$ 
per hectare at square formation and followed by second spray of biovita liquid at $750 \mathrm{ml}$ per hectare at flowering (1.93 and 22.2, respectively). Whereas, application of only recommended dose of fertilizer recorded significantly least number of monopodia and sympodia branches (1.54 and 16.7, respectively) compared to other treatments.

Effect of biovita on yield parameters of cotton: Application of biovita granule and liquid was having greater influence on yield parameters of cotton. It increases the number of squares, flowers, bolls and boll retention per cent per plant in cotton (Tables 3, 4 and 5). Application of biovita granule at $12.5 \mathrm{~kg}$ per hectare at one month after sowing followed by first spray of biovita liquid at $500 \mathrm{ml}$ per hectare at square formation followed by second spray of biovita liquid at $750 \mathrm{ml}$ per hectare at flowering and followed by third spray of biovita liquid at $750 \mathrm{ml}$ per hectare at boll formation recorded significantly maximum flowers, bolls, boll weight and boll retention per cent (34.3 at 75 DAS, 33.1, $114.8 \mathrm{~g}$ and $90.3 \%$ at 110 DAS, respectively) and which was onpar with the application of biovita granule at $10.0 \mathrm{~kg}$ per hectare at one month after sowing followed by first spray of biovita liquid at $500 \mathrm{ml}$ per hectare at square formation followed by second spray of biovita liquid at $750 \mathrm{ml}$ per hectare at flowering and followed by third spray of biovita liquid at $750 \mathrm{ml}$ per hectare at boll formation (33.5 at 75 DAS, $32.5,111.6 \mathrm{~g}$ and $89.0 \%$ at $110 \mathrm{DAS}$, respectively) and application of biovita granule at $12.5 \mathrm{~kg}$ per hectare at one month after sowing followed by first spray of biovita liquid at $500 \mathrm{ml}$ per hectare at square formation and followed by second spray of biovita liquid at $750 \mathrm{ml}$ per hectare at flowering (32.8 at 75 DAS, $32.1,109 \mathrm{~g}$ and $87.1 \%$ at $110 \mathrm{DAS}$, respectively). Whereas, application of only recommended dose of fertilizer recorded significantly lower yield parameters compared to other treatments.

Effect of biovita on cotton (seed+lint) and green biomass yield: The pooled data on seed+lint and green biomass yield of cotton as influenced by different rate of biovita granule and liquid application is presented in Table 5. Cotton yield and green biomass yield were significantly higher in the treatment with the application of biovita granule at $12.5 \mathrm{~kg}$ per hectare at one month after sowing followed by first spray of biovita liquid at $500 \mathrm{ml}$ per hectare at square formation followed by second spray of biovita liquid at $750 \mathrm{ml}$ per hectare at flowering and followed by third spray of biovita liquid at $750 \mathrm{ml}$ per hectare at boll formation $(1450 \mathrm{~kg} / \mathrm{ha}$ and $1463 \mathrm{~g} / \mathrm{plant}$, respectively) and which was onpar with the application of biovita granule at $10.0 \mathrm{~kg}$ per hectare at one month after sowing followed by first spray of biovita liquid at $500 \mathrm{ml}$ per hectare at square formation followed by second spray of biovita liquid at $750 \mathrm{ml}$ per hectare at flowering and followed by third spray of biovita liquid at $750 \mathrm{ml}$ per hectare at boll formation $(1377 \mathrm{~kg} / \mathrm{ha}$ and $1439 \mathrm{~g} / \mathrm{plant}$, respectively). Whereas, application of only recommended dose of fertilizer recorded significantly least cotton and green biomass yield compared to other treatments. The average per cent of increase in yield in biovita applied treatments $\left(T_{1}\right.$ to $\left.T_{8}\right)$ over the no application of biovita treatment $\left(\mathrm{T}_{9}\right)$ was $7.13 \%$. Mondino et al. (2004) reported that, application of growth regulators enhances the boll weight and boll number per plant in cotton. Plant growth regulators have the potential to promote crop earliness, square and boll retention, higher nutrient uptake, and keeping vegetative and reproductive growth in harmony to improve lint yield and quality (Robertson and Cothren, 1993 and Oosterhuis and Zhao, 1993).

Effect of biovita on economics of cotton: Obviously, application of biovita granule at $12.5 \mathrm{~kg}$ per hectare at the time of sowing followed by first spray of biovita liquid at $500 \mathrm{ml}$ per hectare at square formation followed by second spray of biovita liquid at $750 \mathrm{ml}$ per hectare at flowering and followed by third spray of biovita liquid at $750 \mathrm{ml}$ per hectare at boll formation recorded higher cost of cultivation $(27,275 / \mathrm{ha})$ and gross returns $(65,250 / \mathrm{ha})$ compared to other treatments. Further, Net returns and B:C ratio were significantly higher in the treatment with the application of biovita granule at $12.5 \mathrm{~kg}$ per hectare at one month after sowing followed by first spray of biovita liquid at $500 \mathrm{ml}$ per hectare at square formation followed by second spray of biovita liquid at $750 \mathrm{ml}$ per hectare at flowering and followed by third spray of biovita liquid at $750 \mathrm{ml}$ per hectare at boll formation (Rs.37,975/ha and 2.39, respectively) and which was onpar with the application of biovita granule at $10.0 \mathrm{~kg}$ per hectare at one month after sowing followed by first spray of biovita liquid at $500 \mathrm{ml}$ per hectare at square formation followed by second spray of biovita liquid at $750 \mathrm{ml}$ per hectare at flowering and followed by third spray of biovita liquid at $750 \mathrm{ml}$ per hectare at boll formation (Rs.34,690/ha and 2.29, respectively) compared to other treatments (Table 6). Similar results also reported by Ramesh Kumar Gumber (2007) stated that application of biovita (growth regulators) enhance cotton yield and increases net returns in American cotton.

\section{Conclusion}

The study concluded that application of biovita granule at 12.5 or $10.0 \mathrm{~kg}$ per hectare at one month after sowing followed by first spray of biovita liquid at 500 $\mathrm{ml}$ per hectare at square formation followed by second spray of biovita liquid at $750 \mathrm{ml}$ per hectare at flowering and followed by third spray of biovita liquid at 750 $\mathrm{ml}$ per hectare at boll formation was significantly increases the yield and yield parameters of cotton over the treatment with no application of biovita granules and liquid. Further, Biovita granule application significantly improved the germination per cent in cotton. 


\section{REFERENCES}

Anonymous, (1995). Hybrid cotton production technology, National Level Training Mannual Agriculture Research Station, Dharwad, Karnatka, India pp4-47

Eshanna, M.R., S.B. Hadpad, I.S. Katageri, B.M. Khadi (2004). Effect of growth regulators and nutrients on seed and economic traits in cotton (G. hirustum). Pp332 -334 In Proc. International Symposium on Strategies for Sustainable Cotton Production - A Global Vision., held at UAS, Dharwad from November 23-25

Gomez, K.A. and Gomez, A.A. (1984). Statistical Procedures for Agricultural Research, John Wiley \& Sons. Inc., New York.

Karev, K. (1980). Effect of cotton fertilization with boron, zinc, molybdenum, and manganese in cinnamon forest soil. Biological Abstracts 72: 65-82

Khuzhanazarov, S.H., N. Dzhumaev and Manov, S.H.
(1983). Effect of copper and zinc in the composition of basal fertilizers on yield of fine fibre cotton. Field Crop Abstract 37: 780

Mondino, M.H., Peterlin, O.A. and Garay, F. (2004). Response of late planted cotton to the application of a growth regulator (Chlorocholine chloride, Cycocle 75. Experimental Agriculture, 40: 381-387

Oosterhuis, D.M. and Zhao, D. (1993). Physiological effect of PGR IV on the growth anfd yield of cotton. Pp 1270 in 1993 Beltwide Cotton Conference Proceedings

Ramesh Kumar Gumber, Manpreet Singh and Prabhu Dayal Kumawat, (2007). Growth regulators for enhancing seed cotton yield, yield components and fibre quality in american cotton (Gossypium hirsutum L.) Punjab Agricultural University, Abohar, India

Robertson, W.C. and Cothren, J.T. (1993). "PGR IV effects on boll distribution, lint yield, and fiber quality." 1993 Beltwide Cotton Conference Proceedings, p. 1,287 